\title{
DRAGONFLY ASSEMBLAGES IN THE UPPER PARTS OF THE RIVER TISZA: A COMPARISON OF LARVAL AND EXUVIAL DATA IN THREE CHANNEL TYPES
}

\author{
István Kolozsvári ${ }^{1,2}$, LÁszló József Szabó ${ }^{1}$ and GYörgy DévaI ${ }^{1}$ \\ ${ }^{1}$ University of Debrecen, Faculty of Science and Technology, Department of Hydrobiology \\ Egyetem tér 1, Debrecen 4032, Hungary \\ E-mails: szabo.laszlo@science.unideb.hu,devai.gyorgy@science.unideb.hu \\ ${ }^{2}$ Ferenc Rákóczi II. Transcarpathian Hungarian Institute, István Fodor Research Institute \\ Kossuth square 6, Beregove 90202, Ukraine; E-mail: kolozsvaros@gmail.com
}

We studied dragonfly assemblages in the Ukrainian section of the River Tisza, which still shows several natural (unregulated) properties. In 2010 and 2011 larvae and exuviae were collected in the vicinity of the villages Vilok (Вилок, Tiszaújlak), Nove Szelo (Нове Село, Tiszaújhely), Tiszobikeny (Тисабикень, Tiszabökény) and of the towns Vinohragyiv (Виноградів, Nagyszőlős) and Huszt (Хуст, Huszt). We collected our samples from 8 sites in the main channel, 2 sites in side channels and 3 sites in two dead channels. We collected 255 larvae and 1587 exuviae, from which 8 species of dragonflies were identified [Gomphus vulgatissimus (Linnaeus, 1758), Stylurus flavipes (Charpentier, 1825), Onychogomphus forcipatus (Linnaeus, 1758), Ophiogomphus cecilia (Fourcroy, 1785), Somatochlora metallica (van der Linden, 1825), Calopteryx splendens (Harris, 1782), Platycnemis pennipes (Pallas, 1771), and Sympecma fusca (van der Linden, 1820)]. We compared the species composition of dragonflies in the three habitats. In the case of larvae in the main channel G. vulgatissimus $(48.0 \%)$, C. splendens $(29.6 \%)$ and O. forcipatus $(20.8 \%)$ dominated, while in the dead channels C. splendens $(49.5 \%)$ and $P$. pennipes $(23.7 \%)$ were found most frequently. In the side channels G. vulgatissimus, O. forcipatus and C. splendens were the most frequent species. S. flavipes appeared only in the main and side channels, while S. metallica and S. fusca were only detected in the dead channels.

Key words: Upper-Tisza, Odonata, Gomphidae, larvae, exuviae

\section{INTRODUCTION}

The species composition of dragonfly assemblages, to the extent of our knowledge, has not been surveyed in the Ukrainian section of the River Tisza between the village Vilok and the town Huszt. As a consequence of river harnessing in Europe, there are only a few places left that are as unique and natural as the upper section water system of the River Tisza in Ukraine. As a result of the channel and riverbank alterations the rate of water delivery, the quantity of alluvial transportation and the efficiency of river erosion increased in most places in Europe, resulting in a significant decrease in the number and density of macroinvertebrates (Doeg et al. 1987, Bettess 1994, Cserkész-Nagy et al. 2010). 
The research of the Transcarpathian (Ukraine, Zakarpatska region) dragonfly assemblages was started at the end of the 19th century by FrIVALDSZKY (1873), Mocsáry (1876), Kohaut (1896) and DzięDzielewicz (1919). In the first half of the 20th century their work was continued by HrabÁr $(1905,1933)$ and Fudakowski (1935), and more recently by PAvljuk (1990), Gorb et al. (2000), Mauersberger (1994), Dobej and Bondarchuk (1998), Vizslán and Huber (2001), Ryazanova (2007), Holuša (2009), Martynov and Martynov (2002, $2009,2010)$. Unfortunately, the results of the previously mentioned researches

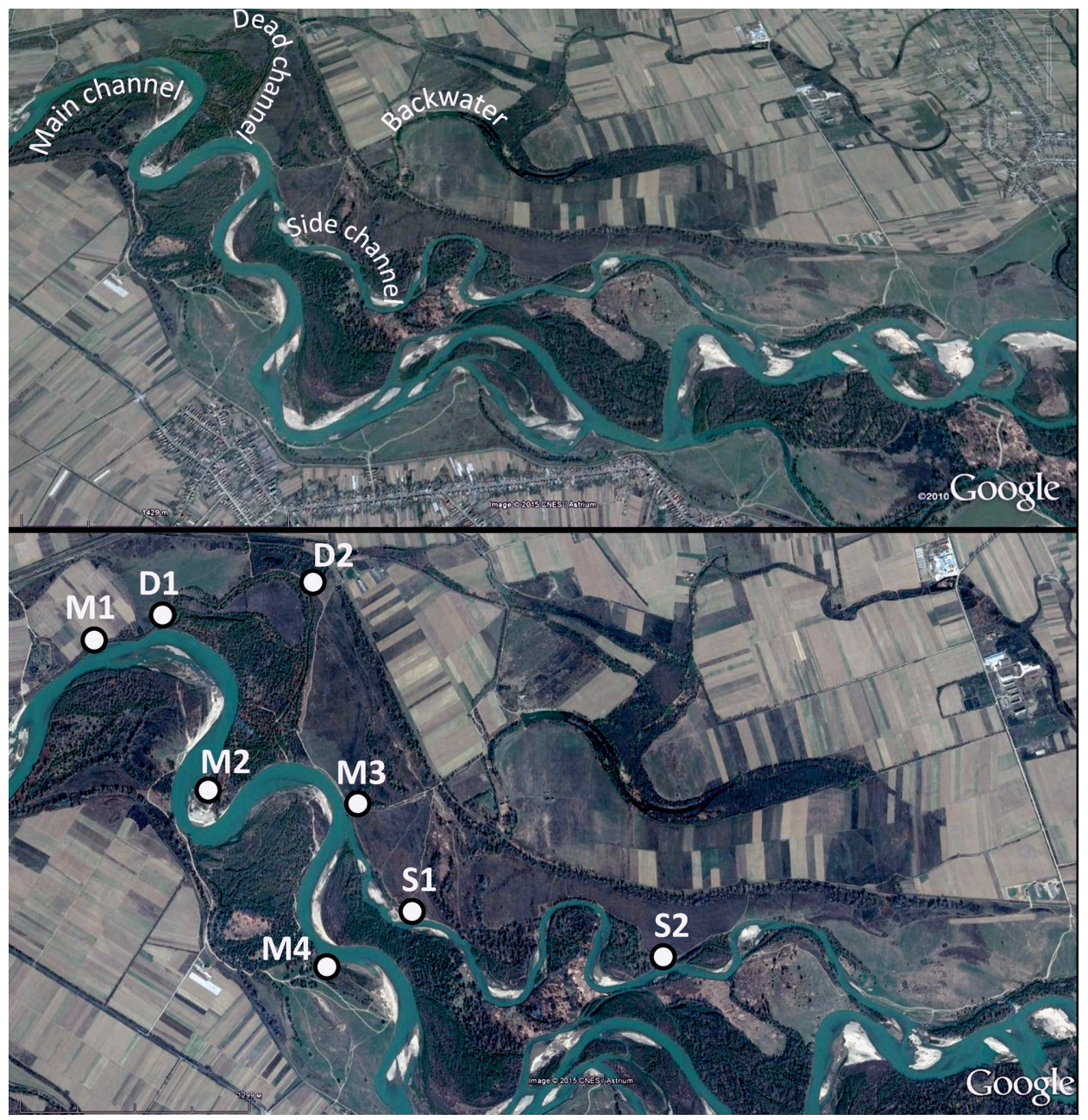

Fig. 1. The anastomosing riverine channel system of the River Tisza around the villages Vilok, Nove Szelo and Tiszobikeny with the presentation of main-side-dead channels and backwater (above) and some sample sites (below) (Google Earth satellite image - 04.05.2012). 
gave only an insufficient overview of the dragonfly assemblages of the River Tisza. In many cases the published sampling sites are difficult to localize, but these studies are useful in obtaining some basic information about certain dragonfly species in the area of Transcarpathia. Some observations on imagos from backwaters at Huszt was published by PAvLjuK (1990) and Gorb et al. (2000), as part of the results of the occasional sampling of macroinvertebrate monitoring by Kovács and GodunKo (2008), Kovács et al. (2008), and from the larvae collection of Kolozsvári and IlLÁr (2009) at Vilok.

However, we still have insufficient knowledge on the species composition and the frequency of dragonfly species. Despite the dams, this section of the River Tisza shows an active river bank and channel forming tendency, resulting in side and dead channels that follow the main channel's line. In the Tisza section above Huszt mostly the meandering tendency prevails, while in the area of Nove Szelo and Tiszobikeny the anastomosing feature is more determinative (Figs 1-3). Leaving the Huszt gate, the river builds wider river flats, and its real expansion occurs in the section between Vinohragyiv and Vilok (Gönczy \& Molnár 2004). After the Huszt gate, the River Tisza begins

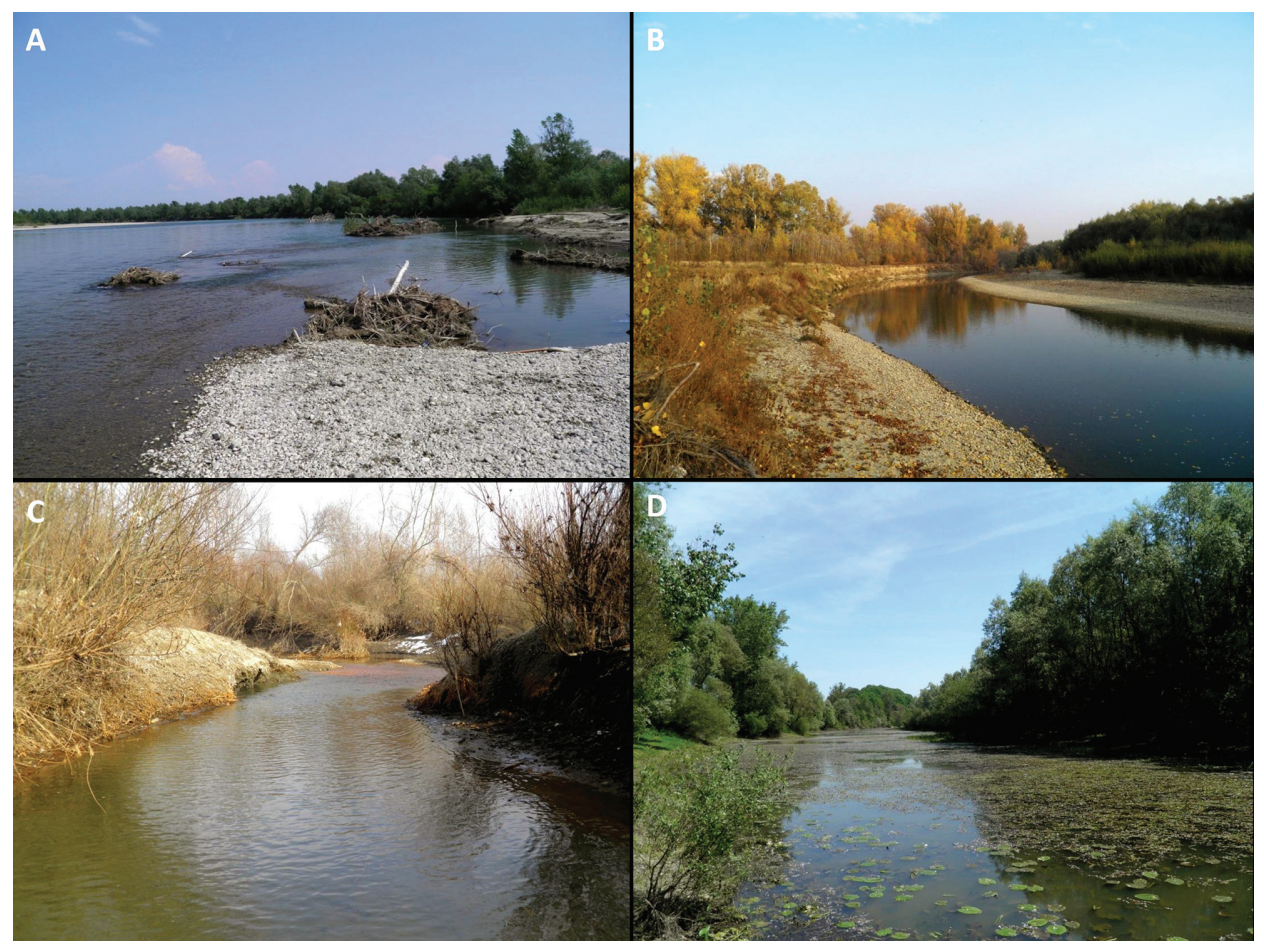

Fig. 2. The typical channel types of the examined section of the River Tisza: $A=$ main channel at Vilok; B = side channel at Nove Szelo; C = dead channel at Vilok; D = backwater of Huszt. 
to dump the sediment that mainly consists of pebbles and granules, thus an inland delta is created, which results in the emergence of an irregularly branching and reconnecting network (anastomosing) channel morphology type (Fig. 1). This river network consists of ",bed material supply dominated" channels (Снurch 1992). The mid-channel inlands, which are built of rough sediment, rapidly wander. On these sections the river channel is rather unstable, heavy floods may totally reconstruct it. In case of the anastomosing channel type the main channel may be followed by some side channels and dead channels. In the case of anastomosis the main channel's and the side channels' water transport relation is difficult to estimate, the latter occasionally runs into the former then they branch out again and proceed across the flood basin. The dead channels are usually situated so high compared to the main channel that they only transport water when the water is above the typical level. Their lifetime may be long because their channel forming stream is slow (GÁBRIs \& Lóczy 2013). We would like to emphasize that, on the basis of their characteristics, the dead channels at Vilok and Vinohragyiv cannot be regarded as backwaters separated from the main channel. They can be considered to be side channels that have not clogged up from the main channel yet. However, owing partly to the main channel's deepening tendency and partly to the side channels' continuous sedimentation, the water flows in the channels intermittently (Figs 1-2). They are clogged up from the main channel partly because of the deepening tendency of the main channel and partly because the sediments in the side channel's water flows through the channels quickly. In case of the dead channels at Vilok and Vinohragyiv we can talk about channel sections which have not separated from the main or side channels yet, but their bottom level is higher where their flow starts, so water only periodically flows continuously in them, when the water level is higher than the typical water level (NÉMETH 1954). The oxbow lakes contrary to the dead channels are created by natural or artificial (man-made) cuts through the channels (ANGELIER 2003, Lóкі \& Szabó 2006), and are resupplied only in time of heavy floods, when the river runs over its banks (mostly with inundation).

The side and dead channels that follow the main channel of the river may have peculiar natural habitats with specific characteristics in the fauna. The continuously changing river channel and shore structure make it difficult to study the dragonfly populations, as well as detecting and monitoring the occasional changes in the populations of indicator species. The composition of river-bed materials and its occasional realignment influences the ecesis of benthic organisms (Brookes 1994, Carling 1992, Beisel et al. 1998, Robert 2003, BERECZKI et al. 2012, FelD et al. 2014). The realignment of the river-bed materials, caused by the regular flood subsiding, may affect the territorial relocation of the larvae of riverine dragonflies that are sensitive to habitat disturbance (Müller 1995, 2004, SuHling \& Müller 1996). Water quality degradation and 
immoderate fluctuation of water regime throughout Europe are serious dangers to the survival of riverine dragonflies, therefore the exploration and protection of their existing natural habitats are among the most important tasks of conservation biology (JАKAB \& DÉVAI 2008). In the present study we aimed to survey the dragonfly populations in the upper parts of the River Tisza and to measure and compare the species composition of their assemblages in three related habitats: in the main channel, the side channels and the dead channels.

\section{MATERIAL AND METHODS}

We collected the larvae of dragonflies during the autumn of 2010 and spring of 2011 (from 06.10.2010 to 30.07.2011), while exuviae were collected between May and July in 2011 between the village of Vilok and the town of Huszt along the River Tisza. The larvae were captured with a net. Its lower straight frame was $40 \mathrm{~cm}$ with mesh size of $1 \mathrm{~mm} \times 1 \mathrm{~mm}$. The larvae were preserved in $70 \%$ ethyl alcohol. Exuviae were collected by hand-picking

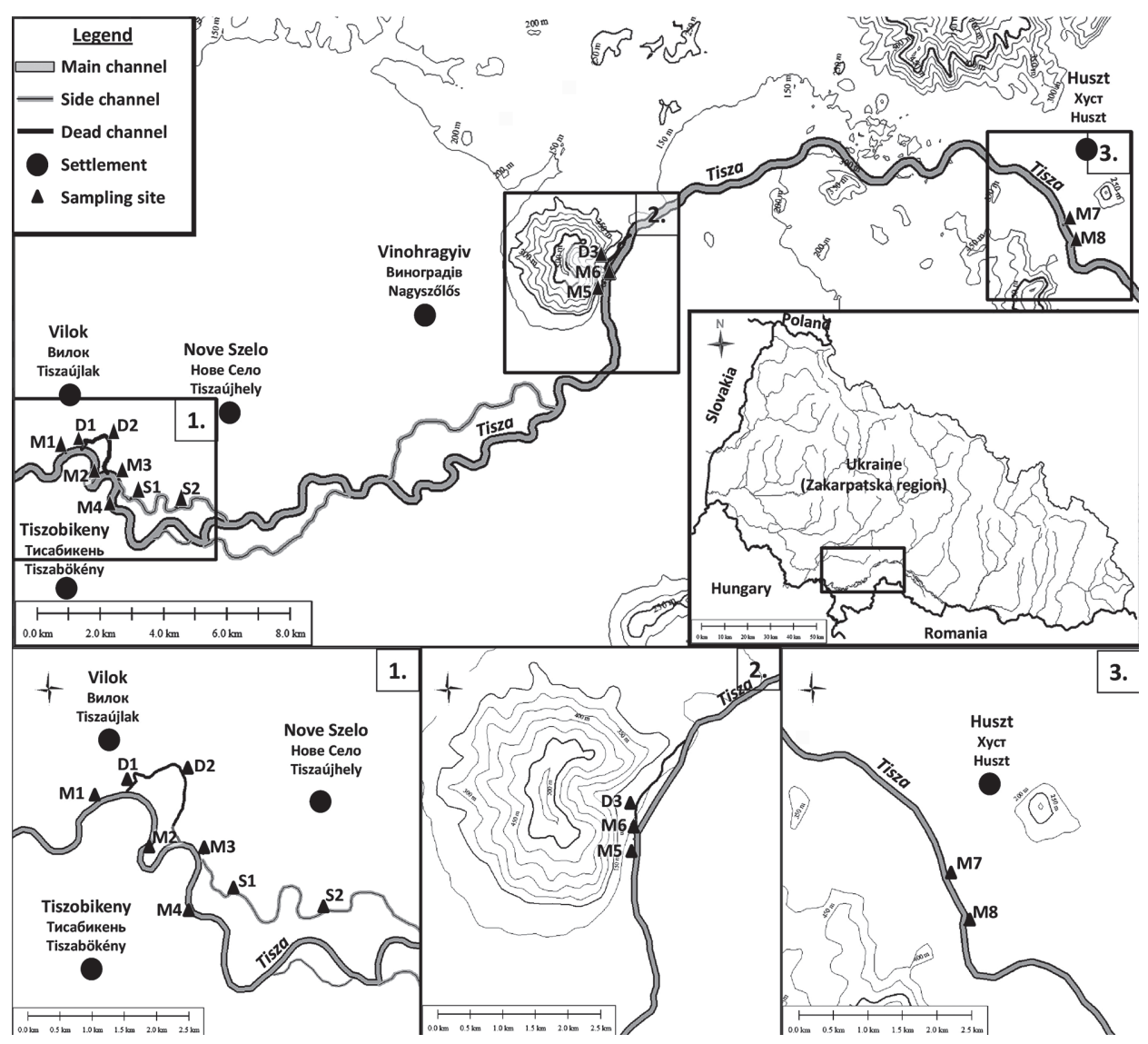

Fig. 3. Our study sites along the River Tisza between the village Vilok and town Huszt. 
Table 1. Topographical position of the sampling sites.

\begin{tabular}{|c|c|c|c|c|}
\hline Site & UTM coordinates & Geocoordinates & Villages and towns & $\begin{array}{r}\text { a.s.l. } \\
(\mathrm{m})\end{array}$ \\
\hline M1 & 34U 06383335329270 & $\begin{array}{l}48^{\circ} 06^{\prime} 06.1609^{\prime \prime} \mathrm{N} \\
22^{\circ} 51^{\prime} 29.2849^{\prime \prime} \mathrm{E}\end{array}$ & Vilok (Вилок, Tiszaújlak) & 115 \\
\hline M2 & 34U 06389665328503 & $\begin{array}{l}48^{\circ} 05^{\prime} 43.7631^{\prime \prime} \mathrm{N} \\
22^{\circ} 52^{\prime} 02.8677^{\prime \prime} \mathrm{E}\end{array}$ & Vilok (Вилок, Tiszaújlak) & 117 \\
\hline D1 & 34U 06387655329442 & $\begin{array}{l}48^{\circ} 06^{\prime} 11.6911^{\prime \prime} \mathrm{N} \\
22^{\circ} 51^{\prime} 50.1321^{\prime \prime} \mathrm{E}\end{array}$ & Vilok (Вилок, Tiszaújlak) & 115 \\
\hline D2 & 34U 06395695329697 & $\begin{array}{l}48^{\circ} 06^{\prime} 18.8611^{\prime \prime} \mathrm{N} \\
22^{\circ} 52^{\prime} 29.5722^{\prime \prime} \mathrm{E}\end{array}$ & Vilok (Вилок, Tiszaújlak) & 116 \\
\hline M3 & 34U 06398535328402 & $\begin{array}{l}48^{\circ} 05^{\prime} 36.7841^{\prime \prime} \mathrm{N} \\
22^{\circ} 52^{\prime} 41.7301^{\prime \prime} \mathrm{E}\end{array}$ & $\begin{array}{l}\text { Nove Szelo (Нове Село, } \\
\text { Tiszaújhely) }\end{array}$ & 118 \\
\hline S1 & 34U 06402795327763 & $\begin{array}{l}48^{\circ} 05^{\prime} 15.6621^{\prime \prime} \mathrm{N} \\
22^{\circ} 53^{\prime} 01.5013^{\prime \prime} \mathrm{E}\end{array}$ & $\begin{array}{l}\text { Nove Szelo (Нове Село, } \\
\text { Tiszaújhely) }\end{array}$ & 118 \\
\hline S2 & 34U 06417095327511 & $\begin{array}{l}48^{\circ} 05^{\prime} 06.6197^{\prime \prime} \mathrm{N} \\
22^{\circ} 54^{\prime} 09.9913^{\prime \prime} \mathrm{E}\end{array}$ & $\begin{array}{c}\text { Nove Szelo (Нове Село, } \\
\text { Tiszaújhely) }\end{array}$ & 119 \\
\hline M4 & 34U 06397565327540 & $\begin{array}{l}48^{\circ} 05^{\prime} 08.9130^{\prime \prime} \mathrm{N} \\
22^{\circ} 52^{\prime} 36.0323^{\prime \prime} \mathrm{E}\end{array}$ & $\begin{array}{c}\text { Tiszobikeny (Тисабикень, } \\
\text { Tiszabökény) }\end{array}$ & 118 \\
\hline M5 & 34U 06552895334549 & $\begin{array}{l}48^{\circ} 08^{\prime} 42.7427^{\prime \prime} \mathrm{N} \\
23^{\circ} 05^{\prime} 15.6611^{\prime \prime} \mathrm{E}\end{array}$ & $\begin{array}{l}\text { Vinohragyiv (Виноградів, } \\
\text { Nagyszőlős) }\end{array}$ & 142 \\
\hline M6 & 34U 06553695334794 & $\begin{array}{l}48^{\circ} 08^{\prime} 50.7019^{\prime \prime} \mathrm{N} \\
23^{\circ} 05^{\prime} 19.8003^{\prime \prime} \mathrm{E}\end{array}$ & $\begin{array}{c}\text { Vinohragyiv (Виноградів, } \\
\text { Nagyszőlős) }\end{array}$ & 141 \\
\hline D3 & 34U 06553305334864 & $\begin{array}{l}48^{\circ} 08^{\prime} 52.9597^{\prime \prime} \mathrm{N} \\
23^{\circ} 05^{\prime} 17.9753^{\prime \prime} \mathrm{E}\end{array}$ & $\begin{array}{c}\text { Vinohragyiv (Виноградів, } \\
\text { Nagyszőlős) }\end{array}$ & 142 \\
\hline M7 & 34U 06697435336511 & $\begin{array}{l}48^{\circ} 09^{\prime} 33.0524^{\prime \prime} \mathrm{N} \\
23^{\circ} 16^{\prime} 57.3402^{\prime \prime} \mathrm{E}\end{array}$ & Huszt (Хуст, Huszt) & 159 \\
\hline M8 & 34U 06699895335852 & $\begin{array}{l}48^{\circ} 09^{\prime} 11.5056^{\prime \prime} \mathrm{N} \\
23^{\circ} 17^{\prime} 08.3128^{\prime \prime} \mathrm{E}\end{array}$ & Huszt (Хуст, Huszt) & 160 \\
\hline
\end{tabular}

from river banks and plants on the channel or banks. For identification of the larvae and exuviae the works of Askew (2004), Bellmann (2007), and Gerken and Sternberg (1999) were used.

During our collections, $30 \mathrm{~m}$ long channel and riverside stretches were marked out at the villages Vilok, Nove Szelo, Tiszobikeny and the towns of Vinohragyiv and Huszt in the main channel, and also at Nove Szelo in the side channels, and at Vilok and Vinohragyiv in the dead channels (Fig. 3, Table 1). The two furthest sites in our study [M1 and M8] showed a $45 \mathrm{~m}$ difference in their elevations a.s.l. (Table 1). Our sampling sites can be divided into two main groups based on the features of the terrain. The sites at Vilok, Nove Szelo and Tiszobikeny are mainly flat, while the ones at Vinohragyiv and Huszt are at foothill stands. Typical river bank types in this section of the River Tisza are point bars, cut banks and artificially reconstructed protected banks. Heavy rains are frequently followed by quick water level fluctuations. As spates occur, river bank changes are frequent on the unprotected 
river banks (in some places even on the protected ones), which continuously transform the typical natural habitats of the area. Regular larvae and exuviae collections are hindered by river bank displacements, transformation of the river bank structure, alluvium rearrangements, regular spates, and gravel mining from the river channel (FARKAs et al. 2011, 2012).

In the riverine habitats high and low periods of water level may alternate within a year. The dead channels' water regime is only continuous at those times when the water level is above the typical level, therefore during immoderately dry periods the open water surface may decrease drastically. However, during flooded periods the channel's intense realignment may occur (Németh 1954, Angelier 2003, Lóki \& Szabó 2006). The fauna of the dead channels depends on the actual water regime of the river. The river channel, river banks, riverine and riverside habitats are continuously changed by the occasional abrupt increase of water and alluvium transportation (ANGelier 2003, HofFmann \& GABet 2007). When the river beds do not get flowing water for a longer period of time, still water species may occur, which might almost totally be washed away by the next larger flood. Consequently, species assemblages may show a different composition in early autumn and the next spring in the dead channels.

The distribution of larvae and exuviae among the sampling sites considering the whole species assemblages was tested with the help of the Mantel test, and in case of the decisive species paired Wilcoxon test was used. We chose our sampling sites so as to cover the typical characteristics of the bank and channel structures of the dragonfly habitats most completely. We analysed our data on the different types of river channels with the help of ordination methods (PCA, NMDS) and agglomerative cluster analysis. For NMDS and cluster analysis the Morisita similarity index was selected, as this index is the least sensitive to differences in sample size (WoldA 1981). To clarify the role of species and the extent of their contribution to the differentiation Similarity Percentage analysis (SIMPER; Clarke 1993) was used. The comparison of species assemblages of the three riverine habitat types was accomplished in R 3.1.0 environment with two multivariate methods. During the IndVal analysis [Indicspecies 1.7.4 package (De CÁceres \& Legendre 2009, De CÁceres \& JANSEN 2014)] indicator species and species assemblages were searched for the given riverine habitat type. With the help of the Classification tree [Tree 1.0-35 package (Ripley 2014)] different riverine habitats were classified based on the similarity of their dragonfly assemblages. The statistical analyses were accomplished with the Microsoft Excel and Past 2.17 (Hammer et al. 2001) computer program packages. The transcription of settlement names follows the form suggested by Molnár and Molnár (2005). The cartographic representation of the sampling sites was carried out using the Environmental Systems Research Institute (ESRI) ArcGIS 10.0 - ArcMap geoinformatics software.

\section{RESULTS AND DISCUSSION}

We collected altogether 255 larvae and 1587 exuviae in 13 sampling sites, containing 8 dragonfly species. 125 larvae and 1316 exuviae were collected from the main channel, 33 larvae and 211 exuviae from the side channels and 97 larvae and 60 exuviae from the dead channels. The samples of the collected larvae usually contained a low number of items. This is supported by the results of the Mantel test that we used to compare the larvae and exuviae data matrices. The two matrices show major, but not significant deviation (Morisita index, $\mathrm{R}=0.115, p$ (uncorr.) $=0.277$ ). In case of the quantitatively 
Table 2. Species composition of the collected larvae in the examined water bodies expressed as percentages.

\begin{tabular}{cccccccccc}
\hline Channel & $\begin{array}{c}\text { G. vul- } \\
\text { gatis- } \\
\text { simus }\end{array}$ & $\begin{array}{c}\text { S.fla- } \\
\text { vipes }\end{array}$ & $\begin{array}{c}\text { O. } \\
\text { forcipa- } \\
\text { tus }\end{array}$ & $\begin{array}{c}\text { O. } \\
\text { cecilia }\end{array}$ & $\begin{array}{c}\text { C. } \\
\text { splend- } \\
\text { ens }\end{array}$ & $\begin{array}{c}\text { P.pen- } \\
\text { nipes }\end{array}$ & $\begin{array}{c}\text { S.me- } \\
\text { tallica }\end{array}$ & $\begin{array}{c}\text { S. } \\
\text { fusca }\end{array}$ & Total \\
\hline Main & 48.0 & 0 & 20.8 & 0 & 29.6 & 1.6 & 0 & 0 & 125 \\
Side & 51.6 & 3.0 & 3.0 & 0 & 39.4 & 3.0 & 0 & 0 & 33 \\
Dead & 5.2 & 0 & 9.3 & 0 & 49.5 & 23.7 & 11.3 & 1.0 & 97 \\
\hline
\end{tabular}

dominant species, the results of the Wilcoxon test on the paired larvae and exuviae data show that there are significant differences in the number of larvae and exuviae on the sampling sites (e.g. G. vulgatissimus: $\mathrm{W}=89.5, p=0.002$; O. forcipatus: $\mathrm{W}=87, p=0.004$ és $C$. splendens: $\mathrm{W}=62, p=0.010)$. We explain this phenomenon by the fluctuations in the water regime, the abrupt changes in the bank and channel morphology, and specific ecological, behavioural and social characteristics of the species.

We identified the following 6 species from the samples collected in the main channel: Gomphus vulgatissimus, Stylurus flavipes, Onychogomphus forcipatus, Ophiogomphus cecilia, Calopteryx splendens and Platycnemis pennipes. The species G. vulgatissimus was the most common dragonfly in both of our larval and exuvial samples. For example, in our main channel samples its contribution was almost $50 \%$ (larvae $48 \%$, exuviae $49.8 \%$ ). The other 3 species [S. flavipes, O. forcipatus and O. cecilia] representing the family of riverine dragonflies (Gomphidae) occurred in lower frequencies than G. vulgatissimus. Based on the number of exuviae, $O$. forcipatus was the second most frequent species in the main channel (Tables $2 \& 3$ ). O. cecilia and S. flavipes appeared only in the sampling sites of the section between Vilok and Tiszobikeny in the main channel. Their larvae could not be collected from the sampling sites of the main channel, while their exuviae could be found during the collections at Vilok and Tiszobikeny. The presence of O. cecilia and S. flavipes at Vilok was confirmed in the earlier works of Kolozsvári and Illár (2009), as well. C. splendens and $P$. pennipes were generally present in the main channel sampling

Table 3. Species composition of the collected exuviae in the examined water bodies in percentages.

\begin{tabular}{lccccccccr}
\hline Channel & $\begin{array}{c}\text { G. vul- } \\
\text { gatis- } \\
\text { simus }\end{array}$ & $\begin{array}{c}\text { S.fla- } \\
\text { vipes }\end{array}$ & $\begin{array}{c}\text { O.for- } \\
\text { cipatus }\end{array}$ & $\begin{array}{c}\text { O. } \\
\text { cecilia }\end{array}$ & $\begin{array}{c}\text { C. } \\
\text { splen- } \\
\text { dens }\end{array}$ & $\begin{array}{c}\text { P.pen- } \\
\text { nipes }\end{array}$ & $\begin{array}{c}\text { S.me- } \\
\text { tallica }\end{array}$ & $\begin{array}{c}\text { S. } \\
\text { fusca }\end{array}$ & Total \\
\hline Main & 49.8 & 1.3 & 46.3 & 2.2 & 0.4 & 0 & 0 & 0 & 1316 \\
Side & 37.0 & 0 & 61.1 & 1.4 & 0.5 & 0 & 0 & 0 & 211 \\
Dead & 85.0 & 0 & 5.0 & 1.7 & 0 & 8.3 & 0 & 0 & 60 \\
\hline
\end{tabular}


sites, but in varying frequency. While in the section of the River Tisza between Vilok and Tiszobikeny all the 4 identified species of riverine dragonflies were present, in the area of Vinohragyiv only 3 species, namely the G. vulgatissimus, $O$. forcipatus and O. cecilia were observed. At Huszt we observed only the G. vulgatissimus and O. forcipatus. In 2004 and 2006 Kovács et al. (2008) carried out macroinvertebrate monitoring in the River Tisza at Hmeliv (Хмелів, Komlós), Luh (Луг, Lonka), Tyacsiv (Тячів, Técső), Visk (Вишково, Visk) and Tekovo (Теково, Tekeháza), and they reported only the presence of $O$. forcipatus.

In the case of the side channels at Nove Szelo the same species were detected as in the main channel of the river: O. forcipatus, G. vulgatissimus and C. splendens were the most frequently appearing larvae. Among the exuviae samples O. forcipatus was the most common (Table 3). The total number of exuviae of the three species showed that in the side channels the number of dragonflies is much lower than in the main channel at Vilok.

Agglomerative cluster analysis separated the dead channels from the main channel and side channels (Fig. 4). Our larval data from dead channels showed the marked presence of particular Zygoptera, while among Anisoptera S. flavipes was missing. In the side channels the representatives of the Anisoptera were dominating. We collected 7 species from dead channels, as the Platycnemis pennipes, Sympecma fusca, Calopteryx splendens, Gomphus vulgatissimus, Onychogomphus forcipatus, Ophiogomphus cecilia, and Somatochlora metallica. Here the quantity of larvae and exuviae was much smaller than in the main channel or the side channels.

The composition of the collected larvae from the two sampling sites of the dead channel at Vilok showed the dominance of $C$. splendens (47 larvae), but

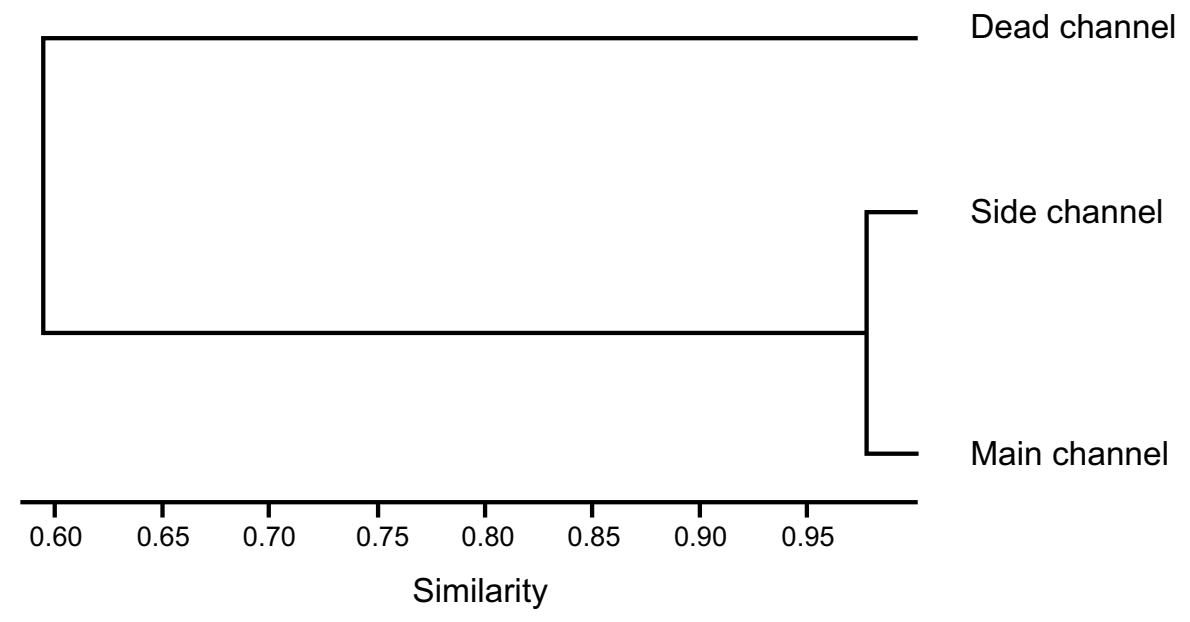

Fig. 4. Results of cluster analysis based on larval and exuvial data grouped according to river channel types (Morisita index, paired group). 
P. pennipes (20 larvae), S. metallica (11 larvae) and O. forcipatus (9 larvae) were also frequent; furthermore G. vulgatissimus (4 larvae) and S. fusca (1 larva) also occurred. In this dead channel only 4 exuviae of G. vulgatissimus were found. From samples of the dead channel at Vinohragyiv we identified P. pennipes (3 larvae, 5 exuviae) and G. vulgatissimus (1 larva, 47 exuviae). We also detected C. splendens (1 larva), O. forcipatus (3 exuviae) and O. cecilia (1 exuvium).

We typically found the two most frequent riverine dragonfly species, the G. vulgatissimus and O. forcipatus in the dead channels. In the dead channel at Vilok, the presence of C. splendens, P. pennipes and S. metallica was significant, but only one specimen of $S$. fusca was found. Only one specimen of O. cecilia was collected from the dead channel at Vinohragyiv.

Agglomerative cluster analysis of the three habitats revealed their similarity structure based on dragonfly assemblages (Fig. 4). It revealed the high resemblance of the main and side channels and also showed that dead channels are separated from these groups (Fig. 4). NMDS mainly supported cluster analysis: the main channel and side channels formed a closely-related overlapping group, while the three dead channel samples were clearly separated from this group (Fig. 5A). PCA was carried out on the grouped larvae and exuviae data and its results also showed the previously described pattern: dead channels were well-differentiated from the main channel and side channels, while the main channel and side channels did not separate from each other substantially (Fig. 5B). According to PCA, the first two main components explained $96.5 \%$ of the total variance ( $79.4 \%$ of the 1 st component). The contribution of G. vulgatissimus and O. forcipatus is important for the 1st component.
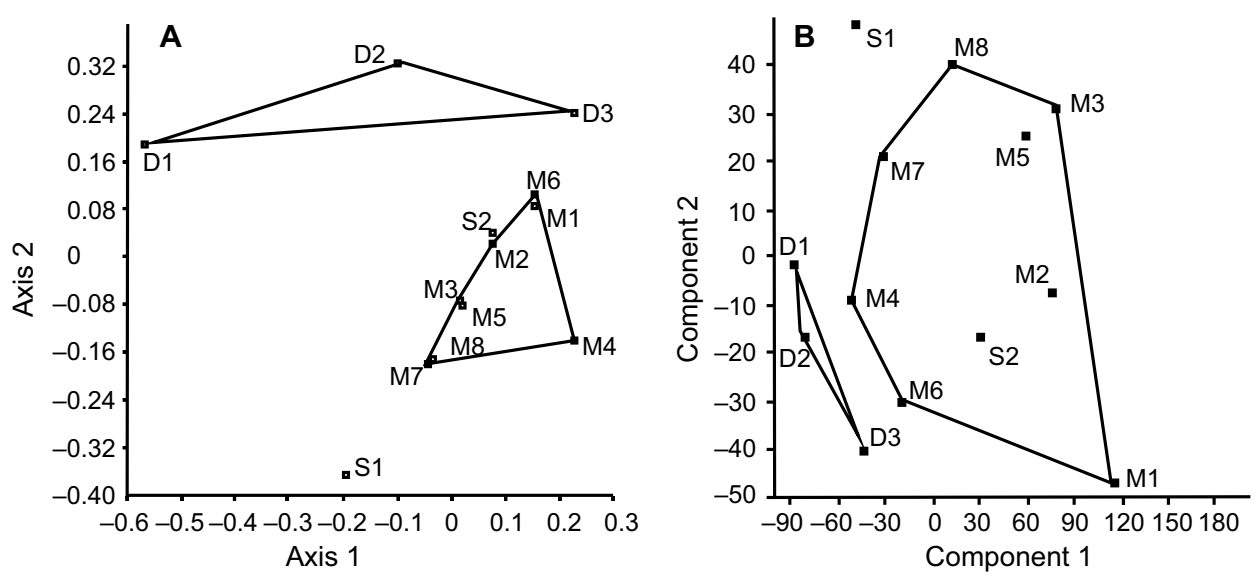

Fig. 5. Results of ordination based on the grouped larval and exuvial data according to sample sites $(\mathrm{A}=\mathrm{NMDS}, \mathrm{B}=\mathrm{PCA})$. 
According to the results of SIMPER the same conclusions can be derived: the differences in the abundance of these species are responsible for $80.5 \%$ differentiation of the three types. In both cases the abundances decreased along the main channel - side channels - dead channels series (G. vulgatissimus: 89.4; 47.5; 18.7; O. forcipatus: 79.5; 65.0; 4.0, in the channel river, side channels and dead channels, respectively). Consersly, if we consider the larval and exuvial data separately, the results were not so unequivocal owing to the previously mentioned reasons. The difference between the side channels and dead channels was more significant; furthermore there is a case when, based on the larvae, one of the side channels resembled more to the main channel, while there is a dead channel that resembles more to the main and side channels.

The comparison of assemblages based on larval and exuvial data by Fisher's exact test showed (Fig. 6) that there was no significant difference in the assemblages of species $(p=0.308)$ between the side and main channels. The dead channels differed significantly from the other two habitats $(p<0.001$ and $p<0.001$ for the dead channels - main channels and dead channels - side channels pairs, respectively). This difference was attributed to the contribution of the non-Gomphidae species. In case of larvae the assemblages of all the three river channel types showed significant differences from one another $(p<$ 0.001). If we examine the distribution of the determinative species along the three different channel types, in the main channel O. forcipatus (20.8\%), in the side channels G. vulgatissimus (51.5\%) and in the dead channels C. splendens $(49.5 \%)$ were the most dominant species. Our exuviae samples from the channel river and side channels did not show a significant difference $(p=0.079)$, while the dead channels differed from both of them significantly $(p<0.001)$.

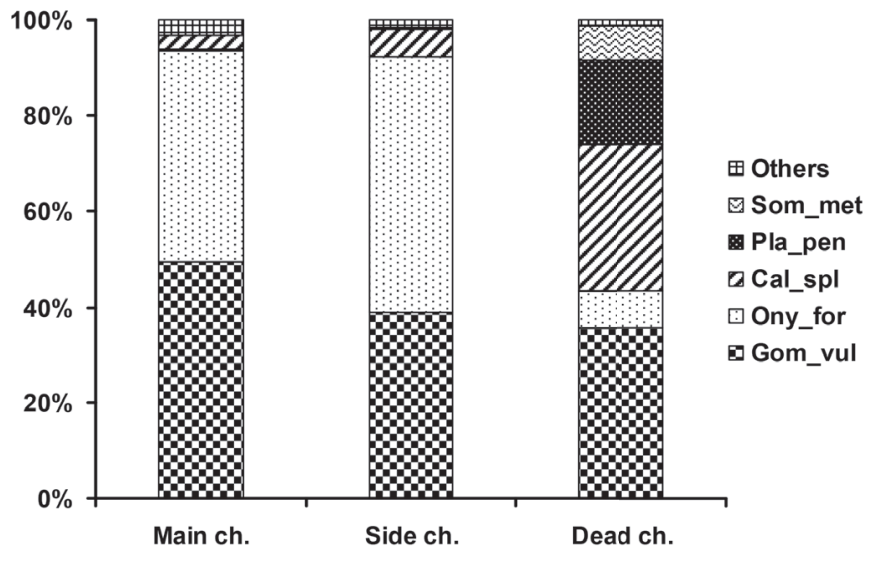

Fig. 6. The composition of assemblages on the three river channel types based on the grouped larval and exuvial data [species with portion of less than $5 \%$ are grouped into the category of Others (Sty_fla, Oph_cec, Sym_fus)]. 
Based on the IndVal analysis of the total species occurrences, it can be stated that out of 8 species only one showed significant indicator value, the S. metallica (indicator value $=0.816 ; p=0.049$ ) that was detected in the dead channels, and its fidelity was also significant $(p=0.667)$. Although $P$. pennipes showed remarkable preference to the dead channels, it was not significant (indicator value $=0.786 ; p=0.167$ ). The analysis revealed the indicator species pair for the main channel: G. vulgatissimus and O. forcipatus (indicator value= $0.823 ; p=0.021)$. The given species-pair occurred in each type and in most of the sites (fidelity $=0.677$ ), but they were most typical in the main channel (their fidelity value was 1.000), so their presence can be considered as a main channel indicator. The analysis based on the exuviae in the main channel and the side channel shows strong significance in the case of $O$. forcipatus (indicator value $=0.996 ; p=0.016$, fidelity $=1.000$ ). Besides the previously mentioned species considering the main and side channels, the indicator value (0.707) of C. splendens was also important, but the correlation cannot be viewed as significant $(p=0.396)$. From the analysis of exuviae that allows species pairs, $G$. vulgatissimus and O. forcipatus proved to be the species-pair indicator for the main channel (indicator value $=0.814 ; p=0.030$ ), and their fidelity also had the maximal value (1.000). The classification tree analysis on the river bed types resulted in partially congruent results. In the construction of the tree, $\mathrm{O}$. forcipatus was taken into consideration, the misclassification error rate was 0.308 , which means that out of 13 sampling sites, four were classified incorrectly related to their real states.

\section{CONCLUSIONS}

Our main objective was to provide an overview on the dragonfly fauna of the River Tisza between the village Vilok and the town Huszt. We also gathered information on the characteristics of their occurrence and quantity based on the data of larvae and exuviae collections. Our samplings were carried out in the area of Vilok (Вилок, Tiszaújlak), Nove Szelo (Нове Село, Tiszaújhely), Tiszobikeny (Тисабикень, Tiszabökény), Vinohragyiv (Виноградів, Nagyszőlős) and Huszt (Хуст, Huszt), in 8 main channel, 2 side channel, and 3 dead channel sites. We collected our samples from 30 meter long channel and riverside stretches. Based in our larval and exuvial data, altogether 8 dragonfly species were detected: Gomphus vulgatissimus, Stylurus flavipes, Onychogomphus forcipatus, Ophiogomphus cecilia, Somatochlora metallica, Calopteryx splendens, Platycnemis pennipes, and Sympecma fusca. The species of Ophiogomphus cecilia is in the Red List of Threatened Species in Ukraine and it is listed in the Bern Convention (TyтAR 2009). In the stretches of the main and side channels, G. vulgatissimus and O. forcipatus were the most dominant dragonflies, while 
in the case of the dead channels $C$. splendens and P. pennipes were the most common species. We found a fine-tuned difference in the case of the species from the Gomphidae family, probably explained by the surface forming work of the river: in the area of Vilok and Tiszobikeny all the four species of riverine dragonflies could be found, while at Huszt only G. vulgatissimus and $O$. forcipatus were present. Our results revealed the mosaic-like structure of the dragonfly fauna, affected by habitat, related to water-regime. We explain the difference in faunal composition between our sites by the difference in the sediments of the different channel sections, caused by the altering strength of water flow. Our results showed that in the dead channels the prominent standing water species were not the ones that are usual in backwaters but those that are typical in slow-flowing water and finer granule sediment channels. However, both standing water species and typical fast-flowing water species may also appear here. This river channel variegation is highly important in the massive maintenance of the dragonfly fauna and the preservation of valuable species assemblages.

The section of the River Tisza between Vilok and Huszt is mostly untouched and an anastomosing riverine main - side - dead channel system is preserved. The given section is unique along the whole channel of the River Tisza. From the point of biodiversity research the significance of such naturally preserved habitats is increasing. The particular ecological relationships are threatened by the strengthening technical interventions, so exploring the natural value of the upper parts of the River Tisza needs priority. If river regulation extends to the given section of the river, there will no longer be an opportunity for studying these natural habitats along the River Tisza.

Acknowledgements - The authors are very much obliged to the reviewers for their thorough and precise work. Furthermore, the authors would like to thank associate professor dr. habil. Péter Pelyvás (Department of English Linguistics, University of Debrecen) for the linguistic corrections of the manuscript. The authors wish to thank for the support of the Gábor Bethlen Fund and Collegium Talentum.

\section{REFERENCES}

Angelier, E. (2003) Ecology of streams and rivers. Science Publishers Inc., Enfield, 215 pp.

Askew, R. R. (2004) The dragonflies of Europe. 2nd ed. Harley Books, Colchester, 308 pp.

Beisel, J. N., Usseglio-Polatera, P., Thomas, S., Moreteau, J. C. (1998) Stream community structure in relation to spatial variation: the influence of mesohabitat characteristics. Hydrobiologia 389: 73-88. doi: 10.1023/A:1003519429979

Bellmann, H. (2007) Der Kosmos Libellenführer. Die Arten Mitteleuropas sicher bestimmen. Franckh-Kosmos Verlags-GmbH \& Co. KG, Stuttgart, 279 pp. 
Bereczki, Cs., Szivák, I., Móra, A. \& Csabai, Z. (2012) Variation of aquatic insect assemblages among seasons and microhabitats in Hungarian second-order streams. Aquatic Insects 34(1): 103-112. doi: 10.1080/01650424.2012.643032

Bettess, R. (1994) Sediment transport and channel stability. Pp. 227-253. In: Calow, P. \& Petts, G. E. (eds): The rivers handbook: hydrological and ecological principles. Vol. 2. Blackwell Scientific Publications, Oxford.

Brookes, A. (1994) River channel change. Pp. 55-75. In: Calow, P. \& Petts, G. E. (eds): The rivers handbook: hydrological and ecological principles. Vol. 2. Blackwell Scientific Publications, Oxford.

CARLing, P. A. (1992) In-stream hydraulics and sediment transport. Pp. 101-125. In: CAlow, P. \& Petts, G. E. (eds): The rivers handbook: hydrological and ecological principles. Vol. 1. Blackwell Scientific Publications, Oxford.

Church, M. (1992) Channel morphology and typology. Pp. 126-143. In: Calow, P. \& Petts, G. E. (eds): The rivers handbook: hydrological and ecological principles. Vol. 1. Blackwell Scientific Publications, Oxford.

Clarke, K. R. (1993) Non-parametric multivariate analyses of changes in community structure. Australian Journal of Ecology 18: 117-143. doi: 10.1111/j.1442-9993.1993.tb00438.x

Cserkész-Nagy, Á., Tóth, T., Vajk, Ö. \& Sztanó, O. (2010) Erosional scours and meander development in response to river engineering: middle Tisza region, Hungary. Proceedings of the Geologists' Association 121: 238-247. doi: 10.1016/j.pgeola.2009.12.002

De Cáceres, M. \& Legendre, P. (2009) Associations between species and groups of sites: indices and statistical inference. Ecology 90 (12): 3566-3574. doi: 10.1890/08-1823.1

De CÁceres, M. \& Jansen, F. (2014) Package 'indicspecies' 1.7.4 - Reposition CRAN (cran.rproject.org/web/packages/indicspecies/indicspecies.pdf).

Добей, В. \& Бондарчук, С. [DовеJ, V. \& BоndARснUк, S.] (1998) Фенологія рівнокрилих бабок (Odonata, Zygoptera) в умовах Закарпатської низовини [The fenology of the dragonflies (Odonata, Zygoptera) on the Transcarpathian lowland]. Науковий вісник Ужгородського Державного Університету, Серія Біологія 5: 137.

Doeg, T. J., Davey, G. W. \& Blyth, J. D. (1987) Response of the aquatic macroinvertebrate communities to dam construction on the Thomson River, Southeastern Australia. Regulated Rivers: Research \& Management 1: 195-209. doi: 10.1002/rrr.3450010302

DziĘDzielewicz, J. (1919) Owady siatkoskrzydłowate ziem Polski (Insecta neuropteroidae Poloniae terrarum). Rozprawy i Wiadomości z Muzeum Dzieduszyckich, Lwów 3: 105-168.

FArkas, A., JАKAB, T. \& Dévai, Gy. (2011) A folyami szitakötők (Odonata: Gomphidae) lárváinak kirepülést megelőző viselkedése a Tisza vízrendszerén exuviumfelmérések alapján [Emergence behaviour of riverine dragonfly (Odonata: Gomphidae) larvae along the Tisza river system based on exuviae surveys]. Acta biologica debrecina, Suppl. oecologica hungarica 26: 53-66.

Farkas, A., Jakab, T., Tóth, A., Kalmár, A. F. \& Dévai, Gy. (2012) Emergence patterns of riverine dragonflies (Odonata: Gomphidae) in Hungary: variations between habitats and years. Aquatic Insects 34(1): 77-89. doi: 10.1080/01650424.2012.643030

Feld, C. K, De Bello, F. \& Doldédec, S. (2014) Biodiversity of traits and species both show weak responses to hydromorphological alteration in lowland river macroinvertebrates. Freshwater Biology 59: 233-248. doi: 10.1111/fwb.12260

FrivaldSZKY, J. (1873) Adatok Máramaros vármegye faunájához [Faunistic data of Máramaros County]. Mathematikai és Természettudományi Közlemények, Budapest, 9(1871)/5: 183-232. 
Fudakowski, J. (1935) Przyczynek do znajomości fauny Czarnogory. Ważki (Odonata) (Contribuants á la faune du Massif de Czarnohora. Libellule). Instytut badawczy lasów Państwowych. Serja A 8: 38-42.

GÁbris, Gy. \& Lóczy, D. (2013) A felszínen lefolyó víz munkája. Pp. 142-179. In: GÁbris, Gy. (ed.): Általános természetföldrajz II. ELTE Eötvös Kiadó, Budapest. [The work of the flowing water on the surface.]

Gerken, B. \& Sternberg, K. (1999) Die Exuvien europäischer Libellen (Insecta, Odonata). Arnika \& Eisvogel, Höxter \& Jena, 354 pp.

Gönczy, S. \& Molnár, J. (2004) A tiszai vízjárás változások valószínű okai [The possible reasons of water regime change of the River Tisza]. Müszaki Szemle (Erdélyi Magyar Müszaki Tudományos Társaság, Kolozsvár) 25: 10-16.

Hammer, Ø., Harper, D. A. T. \& Ryan, P. D. (2001) Paleontological statistics software package for education and data analysis. Paleontologia Electronica 4(1): 1-9. (http://palaeoelectronica.org/2001_1/past/issue1_01.htm)

Hoffman, D. F. \& GABET, E. J. (2007) Effects of sediment pulses on channel morphology in a gravel-bed river. Geological Society of America Bulletin 119(1-2): 116-125. doi: 10.1130/ B25982.1

HolušA, O. (2009) New records of Cordulegaster bidentata and Somatochlora alpestris in the Ukrainian Carpathians (Odonata: Cordulegastridae, Corduliidae). Libellula 28 (3-4): 191-201.

Горб, С. Н., Павлюк, Р. С. \& Спуріс, 3. Д. [Gorb, S. N., Pavljuk, R. S. \& Spuris, Z. D.] (2000) Бабки (Odonata) України: фауністичний огляд [Odonata of Ukraine: a faunistic overview]. Vestnik zoologii 15: 3-155.

Hrabár, S. (1905) Ung és Ugocsa megye szitakötő faunája (The dragonfly fauna of Ung and Ugocsa counties). Rovartani Lapok 12: 101-103.

Грабар, А. [НraваR, А.] (1933) Важки Підкарпатської Русі [Dragonflies of Podcarpatska Rus]. Odonata Carpathorossica - Підкарпатська Русь 10: 34-38.

JAKAB, T., DÉvaI, Gy. (2008) A folyami szitakötők (Odonata: Gomphidae) előfordulása Magyarországon a lárva - és exuviumadatok alapján [The occurrence of the riverine dragonfly-species (Odonata: Gomphidae]. Acta biologica debrecina, Suppl. oecologica hungarica 18: 53-65.

Koнaut, R. (1896) A magyarországi szitakötőfélék természetrajza [The natural history of dragonflies in Hungary]. Királyi Magyar Természettudományi Társulat, Budapest, 78 pp.

Kolozsvári, I. \& Illár, L. (2009) A Tisza tiszaújlaki szakaszán élő szitakötőfajok faunisztikai felmérése [Faunistic survey of the dragonfly fauna of the River Tisza section above Tiszaújlak]. Acta beregsasiensis 8(1): 231-240.

Kovács, T. \& Godunko, R. J. (2008) Faunistical records of larvae of Ephemeroptera, Odonata and Plecoptera from the Zakarpats'ka Region, Ukraine. Folia historico-naturalia Musei matraensis 32: 87-91.

Kovács, T., Godunko, R. J., Juhász, P., Kiss, B. \& Müller, Z. (2008) Quantitative records of larvae of Ephemeroptera, Odonata and Plecoptera from the Zakarpats'ka Region, Ukraine $(2004,2006)$. Folia historico-naturalia Musei matraensis 32: 135-147.

LóкI, J. \& SzAвó, J. (2006) A külsó erók geomorfológiája (The geomorphology of external forces). Kossuth Egyetemi Kiadó, Debrecen, 228 pp.

Мартынов, А. В. \& Мартынов, В. В [Martynov, A. V. \& Martynov, V. V.] (2002) Заметка - Новая находка Cordulegaster bidentatus (Insecta, Odonata) на территории Украины [Note - New Cordulegaster bidentatus (Insecta, Odonata) data from the territory of Ukraine]. Vestnik zoologii 36(3): 24. 
Мартынов, А. В. \& Мартынов, В. В [Martynov, A. V. \& Martynov, V. V.] (2009) Заметка - Новые интересные находки стрекоз (Odonata) в Украине [Note - New interesting finds of dragonflies (Odonata) in Ukraine]. Vestnik zoologii 43(2): 150.

Martynov, A. V. \& Martynov, V. V. (2010) Distribution of Cordulegaster bidentata Selys, 1843 (Odonata, Cordulegasteridae) in Ukraine. Eurasian Entomological Journal 9 (2): 303-307.

Mauersberger, R. (1994) Zur wirklichen Verbreitung von Orthetrum coerulescens (Fabricius) und O. ramburi (Selys) $=$ O. anceps (Schneider) in Europa und die Konsequenzen für deren taxonomischen Rang (Odonata, Libellulidae). Deutsche entomologische Zeitschrift 41: 235-256. doi: 10.1002/mmnd.19940410120

Mocsáry, S. (1876) Adatok Zemplén és Ung megyék faunájához. Jelentés az 1874-ik év nyarán e megyék területén gyüjtött állatokról [Data to the fauna of Zemplén and Ung counties. Report about the collected animals from these counties in the summer of 1874]. Mathematikai és Természettudományi Közlemények 13 (1875)/V: 131-185.

Molnár, J. \& Molnár, D. I. (2005) Kárpátalja népessége és magyarsága a népszámlálási és népmozgalmi adatok tükrében [The population and ethnicity of the Transcarpathian region in the light of census data]. Kárpátaljai Magyar Pedagógusszövetség, Beregszász, 115 pp.

MüLler, O. (1995) Ökologische Untersuchungen an Gomphiden (Odonata: Gomphidae) unter besonderer Berücksichtigung ihrer Larvenstadien. Dissertation, Humboldt-Universität zu Berlin. Cuvillier Verlag, Göttingen, VI + 235 pp.

Müller, O. (2004) Steinschüttungen von Buhnen als Larval-Lebensraum für Ophiogomphus cecilia (Odonata: Gomphidae). Libellula 23 (1-2): 45-51.

NÉmeth, E. (1954) Hidrológia és hidrometria [Hydrology and hydrometry]. Tankönyvkiadó, Budapest, $662 \mathrm{pp}$.

Павлюк, P. C. [Pavljuк, R. S.] (1990) Стрекозы западных областей Украины [The dragonflies of the western districts of Ukraine]. Latvijas Entomologs 33: 37-80.

Ripley, B. (2014) Package 'tree' 1.0-35 - Reposition CRAN (cran.r-project.org/web/packages/ tree/tree.pdf1-19)

Robert, A. (2003) River processes. An introduction to fluvial dynamics. Arnold, London, 214 pp.

Рязанова, Г. И. [Ryazanova, G. I.] (2007) Репродуктивная тактика самцов Lestes sponsa (Hansemann) (Odonata, Zygoptera): индивидуадьный репродуктивный успех или успех популяции [Reproduction tactics in the males of Lestes sponsa (Hansemann) (Odonata, Zygoptera): individual reproduction success or success of the population]. Pp. 287-292. In: Голуб, В. Б. [Goluв, V. В.] (ed.): Проблемы водной энтомологии Pоссии и conpedeльных стран [Questions of aquatic entomology of Russia and adjacent lands]. Издательско-полиграфический центр Воронежского государственного университета, Воронеж.

Suhling, F. \& Müller, O. (1996) Die Flußjungfern Europas (Gomphidae). Die Neue BrehmBücherei 628. Westarp Wissenschaften, Magdeburg \& Spektrum, Heidelberg, 237 pp.

Титар, В. М. [Түтав, V. М.] (2009) Офіогомфус цецилія [Ophiogomphus cecilia]. Pp. 70. In: Акімова, I. А. [Акімоva, I. A.] (еd.): Червона книга України [Red Book of Ukraine]. Глобалконсалтинг, Київ.

Vizslán, T. \& Huber, A. (2001) Odonate records from sub-Carpathia, southwestern Ukraine. Notulae odonatologicae 5(8): 103-105.

WoldA, H. (1981) Similarity indices, sample size and diversity. Oecologia (Berlin) 50: 296-302. doi: 10.1007/BF00344966

Revised version received January 24, 2015, accepted April 10, 2015, published May 29, 2015 